\title{
Transformational Leadership, Dynamic Capabilities and Non-govermental Organizations Performance: Strategy, Structure, and Environment
}

\author{
Diyah Candrawati ${ }^{1}$ and Yasmine Nasution ${ }^{2}$ \\ ${ }^{1,2}$ Faculty of Economic and Business University of Indonesia, Indonesia \\ 1ªdcbright@gmail.com, ${ }^{2}$ yasmine73@ui.ac.id
}

\begin{abstract}
The dynamic capability approach has become a general theoretical framework for analyzing how companies (profit sectors) overcome rapidly changing environments. This paper uses a dynamic capability approach through the presentation of a theoretical framework and empirical evidence about how the relationship between transformational leadership style and dynamic capabilities influences the performance of non-governmental organizations NGOs - (nonprofit sector). The research explained in this paper is only a part of the author's research. The concept and operationalization developed in this paper will be used for further empirical research scheduled in November 2018.
\end{abstract}

Keywords:Competitive environment, dynamic capabilities, non-govermental organizations, oganizations performance, organization structure, and transformational leadersip.

\section{Introduction}

In the global context, recent assessments of non-profit organizations such as non-governmental organizations (NGOs) show that in the last three decades, NGOs are increasingly expanding the impact of their activities around the world and placing them as important role holders in the economic and social development of the society [1]. The same thing happened in Indonesia, especially after the collapse of the new order and the rise of reformation in 1998, where there was a paradigm shift in socio-political dynamics from elite-based to community-based, Indonesian NGOs rose to show increasingly significant roles and performance [2]

Along with the growth of NGOs in both the scale and scope, at the same time NGOs face increasing attention and pressure from the media, policy makers, companies, and among NGOs themselves, for better accountability for the impact of their activities [3]. This situation leads to the questions of accountability for NGOs [4]; [5].

According to Ebrahim [4] in the context of NGOs, accountability is a complex and dynamic concept not only as a means by which individuals and organizations are responsible for their actions, but also in the sense that organizations and individuals take internal responsibility to shape the organization's mission and values, and open themselves to public supervision or external, and to assess performance in relation to organizational goals. Whereas for NGOs realizing accountability is not an easy matter considering that accountability moves in many dimensions and involves many actors, uses various kinds of mechanisms and performance standards and requires organizational response at various levels. This argument reinforces the findings of Edward and 
Hulme [5] that NGOs have multiple accountability, namely "downward" to partners, beneficiaries, their staff and supporters, and "upward" to the trustees, donors and governments where they operate.

To ensure that NGOs can maintain their space to adapt, innovate and maintain a variety of accountability with different constituents, Lewis [6] has offered an effective management model for NGOs to realize organizational accountability. This management model emphasizes organization, environment and outcomes as interrelated aspects. The model was built based on the argument of De Graaf [6] which states that in managing its organization, NGOs need to understand and influence the broader organizational environment outside of their direct field of operation, as it is very crucial for NGOs, because unlike commercial organizations that can measure their success based on their activities and direct results (i.e. production, sales and profits) NGOs must understand and assess the implementation of their work plans in the context of the external dimensions of their environment [6]However, the working environments of NGOs in reality are dynamic and risky [7]As the context in which most NGOs operate tends to be in conditions of scarce resources, institutionally and culturally complex [8]. Especially for NGOs working in politically unstable regions, which may face difficult operating conditions in terms of access to society, staff security and problems with getting accurate information [9] The situation is currently aggravated by increasingly dynamic conditions of environmental change. Thus it can be said that in order to survive NGOs need to have the ability to manage this highly dynamic environment.

Organizational ability to manage or adapt to dynamic environments commonly referred as dynamic capabilities [10] So far, the dynamic capability approach has become a general theoretical framework for analyzing how companies (the private sector) address rapidly changing environments, especially at high speed markets [10]and recognized as a source of sustainable competitive advantage and prerequisites for long-term organizational survival [11]; [12]; [1] But the question then, whether dynamic capabilities be a relevant theoretical framework for analyzing how non-profit organizations such as NGOs manage and adapt to dynamic environments?

The author analyzes the answers to these questions using two approaches. First is the composite management theory approach initiated by Lewis [9] which states that NGO management should not be seen as a completely new field of management, but can be seen in composite terms as a flexible spread of a combination of theory and practice relevant from the world of business and the public sector. Where in practice, NGO management might be understood as a continuous performance of improvisation by referring to ideas and techniques from other fields (profits and the public sector). Then it is possible for organizations such as NGOs to develop dynamic capabilities as profit organizations can develop in different ways. Research on public organizations [12]; [4] has proven that even public organizations can develop and benefit from dynamic capabilities. Second, through organizational learning theory approaches which refer to Korten [13] that the key to the success of NGOs is to translate ambitious plans into practical activities and achieve conformity between needs, program output and competence with its ability to embrace mistakes, learn with people, and build new institutional knowledge and capacity through action. In other words it should has organizational learning abilities. Brown and Convey's [14] in Lewis [6] also stated that organizational learning is the key for NGOs to survive. Thus, considering the high need for organizational learning the authors refer to the approach of Zollo and Winter [15] regarding the concept of dynamic abilities that see organizational learning abilities as a source of dynamic ability, and according to Zott [16] learning mechanisms improve dynamic abilities and offer insight into the evolution of dynamic capabilities [17]. For authors theese idea becomes a valuable clue about the potential of NGOs to develop dynamic abilities through organizational learning. 
But according to Helfat et al. [18] the application of dynamic capabilities must be done intentionally, and managerial perceptions of organizational leaders about the need for change are important triggers for the performance of dynamic capabilities [11] Other studies conducted, also showing that leaders are a key factor to recognize opportunities and make decisions that affect organizational processes [19]because their actions and decisions create an organizational context, affect the response of managers at the middle level and the impact of performance [20], in Cabrales et al., [21]Thus Referring to several arguments about leadership in NGO organizations in the context of dynamic environments for example in Shiva and Suar [22]given that NGOs face external situations and resource crises that are more difficult to predict than profit organizations [23] to overcome it NGOs need transformational leaders (Khandwalla, 1990). In the context of dynamic capabilities itself, Cabrales states that only transformational leaders can directly influence dynamic capabilities because they are able to promote various sensing, seizing, and to reconfigusing organizational resources.

Furthermore, Wilden et al., [24] argue that the realization of potential benefits derived from the dynamic capabilities of the organization depends also on two factors: organizational structure and competitive intensity in the market where the company is embedded. In this case the author also believes that in the context of NGO performance, organizational structure and competitiveness have an influence on the performance of NGOs as well as other forms of organization. [20]

The research that will be conducted aims to find out how the performance of NGOs in a very dynamic environmental context is influenced by transformational leadership style and dynamic ability by considering the contingency effects of competitive structure and intensity in the NGO sector. The research was conducted quantitatively by distributing questionnaires to 2848 NGOs working on thirteen main sectors and operating in various levels of government throughout Indonesia. This study uses the analysis of Structural Equation Modeling (SEM), among others because the Partial Least Squares (PLS) approach is suitable for research that has a theoretical basis that is still lacking where PLS is a causal-predictive analysis in conditions of high complexity and very suitable to develop as suggested by SEM covariance like LISREL

\section{Literatur Review}

\subsection{Transformational Leadership}

Transformational leadership refers to leaders who are able to move followers beyond their immediate interests. [18];[22] Transformational leaders have the ability to attract followers by charism, give individual attention to each subordinate, inspire followers to take on grassroots challenges, and function as a role model for selfless service that provides a rational for its presence other than just money as a consideration for subordinates [22]. Referring to Bass and Avolio [25] transformational leadership has five interrelated dimensions that are: ideal influence (as an attribute), here leaders build trust, inspire strength and pride, and go beyond their own individual interests to their followers; ideal influence (as behavior), leaders act with integrity, talk about their values and beliefs, focus on the desired vision, and consider the moral and ethical consequences of their actions; inspirational motivation, leaders behave in ways that motivate the people around them by giving meaning and challenges to the work of their followers; intellectual stimulation, leaders stimulate the efforts of their followers to be innovative and creative by questioning assumptions, reframing problems and approaching old situations with new ways; and individual considerations, where leaders pay attention to each follower's needs for achievement and growth by acting as a coach or mentor. 


\subsection{Dynamic Capabilities}

Dynamic capability according to Teece et al[10]is "the company's ability to integrate, build, and reconfigure internal and external competencies to address rapidly changing environments". A quite number of studies that support the argument of Teece et al. [26]some of which mention that dynamic capabilities can support the creation of competitive advantage [24]or hold the potential for sustainable competitive advantage and indirectly produce competitive advantage [27]it is also said that companies that adhere to dynamic capabilities improve their performance [28]

Winter [15]through his observations, came to a conclusion that although there are some who argue that dynamic capabilities support the achievement of competitive advantage, his research came to a conclusion that the concept of dynamic capabilities is a useful addition to strategic analysis tool kits, but strategic analysis itself remains a problem understanding how the idiosyncratic attributes of individual companies affect prospects in the context of certain competition.

Although mentioning that the analysis of dynamic capability models shows that it overcomes the problem of resources at the infrastructure level and has some similarities with traditional contingency theory, Medco[18]f said that this similarity can be a source of ideas to decipher and refine models of dynamic capabilities. But according to Medcof, this analysis leaves little doubt that the dynamic ability model is actually a renewed contingency approach (neo-contingency). Whereas Helfat and Peteraf [18], refer to the definition of dynamic abilities from Teece et. al. [29] suggested a new concept that supports a more comprehensive approach to dynamic resourcebased theory, namely capability life cycle (CLC), where in this concept they include all organizational capabilities, 'dynamic' or in other words a source-based perspective dynamic resource-based view. Furthermore Eisenhardt and Martin [12] depart from the understanding that the concept of dynamic capability is an extension of the resource-based perspective (RBV), arguing that dynamic capabilities actually include well-known organizational and strategic processes such as forming alliances and product development whose strategic value lies in their ability to manipulate resources into value creation strategies. Although idiosyncratic, they show similarities or 'best practices' throughout the company. Their extensive structural patterns vary with market dynamism, ranging from strong and grooved routines in a fairly dynamic market to fragile semi-structured at high speeds. They evolved through well-known learning mechanisms. Where the mechanism of learning is in line with the ideas of Zollo and Winter [15]; [15] and Zott [16]that suggested dynamic capabilities can be seen as embedded in routine organizational processes that aim to influence change, where sub-processes that are dynamic capabilities can be classified as routines for variation, selection, or retention, which are materials for evolutionary learning systems. Yi Chien and Han Tsai [17] also mentioned that knowledge resources and learning mechanisms are very important for the development of dynamic capabilities.

\subsection{Organizational Structure}

Hatch and Cunliffe in their book Organization Theory, Modern, Symbolic, Postmodern Perspective [30]stated that organizational structure refers to the relationships between people and the roles and responsibilities they assume in the organization. In simple terms the social structure of an organization is commonly referred to as an organizational structure, by modernist organizational theorists defined as hierarchies, division of labor, and coordination mechanisms.

While Hitt et al., in their book on The Concept Of Strategic Management, put forward the view that effective structures provide the stability that companies need to successfully implement strategies and maintain their current competitive advantages while simultaneously providing flexibility to develop the benefits needed in the future. An effective flexible organizational structure enables companies to tap into current competitive advantages while developing new ones 
that can potentially be used in the future. In other word, organizational structure influences the company's response to change [10]Which is consistent with contingency theory, which confirms that the organizational context presents obstacles that must be adjusted by the company by modifying its structure. Fadeyi and Ajagbe [31]reinforced this argument through the conclusions of the results of their research which stated that organizational performance is highly dependent on organizational structure, when a structure that clearly exists people will perform better, tasks are divided well and productivity increases.Long before the aforementioned arguments, Fredricsson has shown that the pervasive effects of structure offer a reasonable explanation of why companies develop certain ways to make strategic decisions.

\subsection{Competitive Intensity}

Competitivenessisa complex, multidimensional and relative concept, related to the large number of interdependent variables that make it difficult to feel and define. Determining competitiveness itself is a research problem, as well as measuring competitiveness. According to Webster's English Dictionary, 'competitiveness' comes from the Latin word 'competer' which means 'involvement in business competition in a market'. The term commonly used in academics and business practice is 'competitive ability'. ([23]This definition shows that the reason why a company needs 'competitiveness' is because of competition.

Furthermore, according to Hitt et al., [31]when companies conduct maneuvers to obtain profitable positions in the market by carrying out a series of ongoing competitive actions and reap competitive responses among competing companies, competitive competition will emerge. The series of actions and competitive responses that companies need to build or maintain their competitive advantage and increase their market position are called competitive behavior. Whereas all competitive behavior - that is, a series of actions and total responses taken by all companies competing in the market - is called competitive dynamics. Theese competitive behavior of a company will eventually form market characteristics.

Regarding the intensity of competition, industrial organizations theory offers a framework known as the five forces of five forces Michael Porter [32] which is commonly used in the business literature to investigate the competitive environment in a sector (industry). Five competitive forces together manifest the intensity of competition within a sector and form the starting point of strategy formulation.These five Porter forces depart from the concept of an industrial organization (Industrial Organization / IO) to obtain what is then called the five forces that determine competitive intensity and, therefore, describe the attractiveness (or not) of an industry in terms of its profitability. Five of Porter's strengths include the three forces of 'horizontal' competition, namely the threat of substitute products or services, the threat of setting rivals, and the threat of new entrants. Whereas the other two from 'vertical' competition are supplier bargaining power and customer bargaining power. [33]

\section{NGOs Performance}

Performance is one of the most debated concepts and there has never been an agreement between various researchers and theorists on this matter [34]But some researchers argue that the main criterion of organizational performance is the growth and long-term survival of an organization[32]; [28]The diversity of definitions in the scientific literature creates ambiguity rather than clarity in defining performance. Experts argue that for the definition of organizational performance we must consider all activities that occur in different entities and different interests from those involved. As the purpose of the entity. But actually the most important of these performance issues is making the most appropriate instrument for assessing performance. Referring to Herman and Renz, [35] and Gill et al. [35]in Ramadan and Borgonovi [7]it is 
emphasized that the most important thing is the understanding of the right indicators to measure and evaluate performance.

\section{Hypotheses and Research Model \\ a. Research Model}

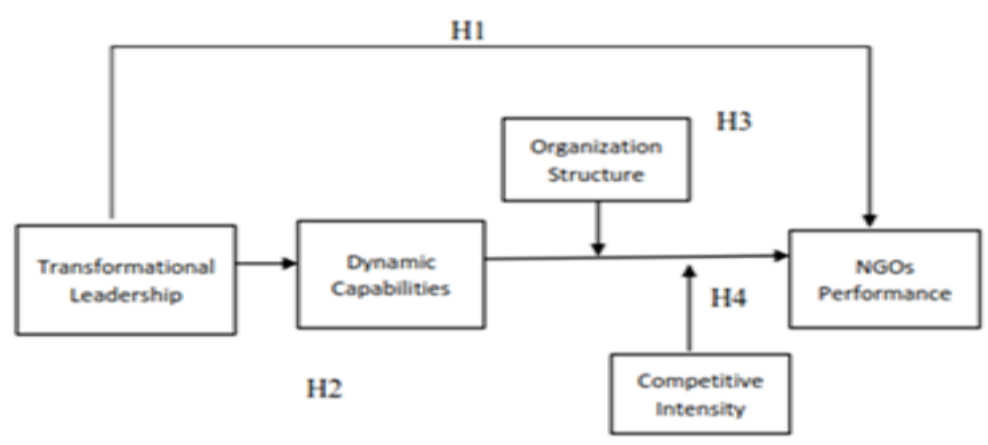

Fig. 1. Research Model

The research model of the study, can be seen in Figure 3.1 which designed to deep investigate the influences of transformational leadership and dynamic capability to NGOs performance. This model related four concept which are transformational leadership, dynamic capabilities, organizational structure, and competitive intensity, to analize their impact on NGO performance. Figure. 3.1.

\section{b. Hypotheses Development}

According to research model, the formulated hypotheses need to be tested, divided into four sections. First, the relationship of transformational leadership with NGOs performance. Second are the relationships of transformational leadership with the elements of dynamic capabilities. Third analyzing the contingency effect of the organization structure to the relationship of dynamic capabilities and NGO performance. And the last hypotheses analyses the impact of competitive intensity to the relationship between dynamic capabilities and NGOs performance.

\section{c. Transformational Leadership and NGOs Performance}

Goel and Kumar [23]in Shiva \& Suar [22]stated that leadership studies so far have shown that transformational leadership styles have characteristics that are needed by leaders in nongovernment organizations[36][25] and compared to transactional leadership styles transformational leaders achieve greater improvements and are considered to be higher in business matters, development, and performance [25]Those are characters needed by such organization like NGOs. Based on the description, the researcher formulated the hypothesis as follows:

H1: Transformational leadership style has a positive effect on the performance of NGO organizations 


\section{d. Tranformational Leadership and Dynamic Capabilities}

Cabrales, et al. [37]research results show that only transformational leaders can directly influence dynamic abilities. This is because transformational leaders are able to promote various sensing, grabbing, and reconfiguring capabilities. Although it is still minimal in the literature data, based on the finding, the researchers submitted hypothesis:

H2: Transformational leadership style have a significant influence on the organizations dynamic capabilities

\section{e. Dynamic Capabilities and Organizational Structure}

Burns and Stalker [29] and Lawrence and Lorsch put forward the idea that the environment dictates the best form of organization. Their ideas are in line with the argument of Teece [29]which states that organizational structure influences the company's response to change. Regarding the form of organizational structure, Burns and Stalker claim that the mechanistic management structure is most suitable for a stable environment. Whereas the flexibility of the form of an organic organization is more in line with a changing environment because it supports innovation and adaptation needed. Some other studies report a positive relationship between organic structure and company adaptability and performance (for example, Zahra and Covin, others argue that formal planning and mechanistic structures improve firm performance (eg, Adler and Borys, 1996; Schwenk and Schrader, [38] revealed that organic versus mechanistic structures on performance are multifaceted, the results of Wilden et al.'s research show that organic organizational structures can better utilize dynamic capabilities. To further proving previous studies result, the researcher proposed the following hypothesis:

H3: Effect of dynamic capabilities on organizational performance increases with a more organic organizational structure.

\section{f. Dynamic Capability and Competitive Intensity}

Through a dynamic capability approach, in his effort to find the causes of competitive advantage, Teece then concluded that the intensity of competition, competitive power approaches and strategic conflict approaches responded by minimizing the intensity of competition through increasing rival costs and exclusive behavior [10] While the dynamic capability approach and resource approach rely on high performance routines that operate 'within the company,' shaped by processes and positions, where pathways of dependency (including increased yield) and technological opportunities mark the way forward [29]. Quoting Wilden et al. Zahra states that companies whose spread dynamic capabilities in highly competitive markets will benefit from dynamic capabilities to support innovation, encourage new market discovery and opportunity identification activities. Whereas the results of Wilden et al 's own study show that when companies compete in environments with limited resources, dynamic capabilities provide the basis for adapting to competitive pressures and to survive. The discussion brings researchers to the following hypothesis:

H4: Effect of dynamic capabilities on organizational performance increases with higher intensity of competition

\section{Methodology}

This study aims to find out how NGOs are able to provide optimal performance in a very dynamic environment through analysis of the relationship of transformational leadership styles and dynamic capabilities by considering the contingency effects of organizational structure and competitive intensity. A quantitative approach using self-administered questionnaire was conducted andthe population and analysis unit of this study are non-profit organizations, namely 
NGOs operating in the territory of the Unitary Republic of Indonesia whose data is taken from the SMERU institution which has a complete and easily accessible NGO database. A total of 2848 NGOs were sent the questionnaire. Respondent as unit of analysis whose are in managerial level or at least as a senior staf considered that they have sufficient knowledge and experience to be able to fill the questioner well.

To measure construct variables, researchers adapts previous studies as follows:

- For transformational leadership construct, researchers refer to the research of Shiva and Suar [22]which uses the Multifactor Leadership Questionnaire (MLQ5) formulated by Bass and Avolio [25]

- To measure the dynamic capabilitiesconstruct, researchers refer to the measurement method used by Wilden et al. which composes it based on the concept of Diamantopoulos and Winklhofer[39], [28] and [26]

- Researchers measured organizational structureconstruct using a five-item version of the measurement scale that referred to Wilden where this measurement scale was adapted from Covin and Slevin [39]This scale assesses the extent to which a company is structured in an organic versus mechanistic way (also called organic). Measured on a 6-point scale, this type of semantic differential scale requires respondents to evaluate the operational management philosophy of each organization. A value of 1 represents a statement relating to a mechanistic structure, while 6 is anchored by a statement that represents an organic structure.

- To measure competitive intensity in the NGO sector, researchers used a measurement mechanism initiated by Schwenger [38] who adopted Porters five forces ([33] to see how NGOs developed the concept of strategy in the face of competitive intensity by adjusting to the natural conditions of NGOs so that the dimensions of five forces already adapted to the context of the NGO [38]

- To measure NGOs performance this study uses a measurement framework suggested by Scholey and Shobel (2016), namely performance measurement for non-profit organizations with a balanced score card approach. There are four main points of view in assessing performance based on this measurement framework: First from a stakeholder perspective. Second, from a financial perspective. Third from an internal perspective. Fourth, the point of view of learning and growth.

\section{Findings}

\subsection{Measurement Model Assesment}

Variable measurements of this study were carried out using SEM with PLS. PLS-SEM is considered more profitable than covariant-based structural equation models when analyzing predictive research models that are in the early stages of theoretical development [40] as conditions in this study. Besides PLS-SEM does not require a large number of samples, Hair et al., [41]stated that the number of representative samples for the SEM method with PLS in the range of 30 to 100 . In reality respondents who were willing to fill out questionnaires were only 30 organizations. 


\begin{tabular}{|l|c|c|}
\hline & $\begin{array}{c}\text { Composite } \\
\text { Reliability }\end{array}$ & $\begin{array}{c}\text { Average } \\
\text { Variance } \\
\text { Extracted } \\
\text { (AVE) }\end{array}$ \\
\hline Competitive Intensity (X4) & 0,813 & 0,689 \\
\hline Dynamic Capabilities (X2) & 0,910 & 0,531 \\
\hline $\begin{array}{l}\text { Transformational Leadership } \\
\text { (X1) }\end{array}$ & 0,938 & 0,561 \\
\hline NGOs Performance (X5) & 0,946 & 0,638 \\
\hline Moderating Effect X3X2 & 1,000 & 1,000 \\
\hline Moderating Effect X4X2 & 1,000 & 1,000 \\
\hline Organization Structure (X3) & 0,893 & 0,677 \\
\hline
\end{tabular}

Table 1. Construct Validity and Reliability

Table 2. R Square

\begin{tabular}{|l|c|c|}
\hline & R Square & $\begin{array}{c}\text { R Square } \\
\text { Adjuste d }\end{array}$ \\
\hline Dynamic Capabilities (X2) & 0,616 & 0,603 \\
\hline NGOs Pe rformance (X5) & 0,789 & 0,734 \\
\hline
\end{tabular}

The table 1 and 2 shows indicators for all constructs having AVE values above 0.5, which means that all indicators in each construct are valid. While output shows accuracy, consistency of the accuracy of measuring instruments for measurement in this study can be seen in the Composite Reliability(CR) table where a construct or variable has good composite reliability if it has composite reliability $\geq 0.7$ and based on the table, all constructs in the study have composite reliability values $>0.7$, which means that all constructs are reliable.

Goodness of fit models are measured using R-square dependent latent variables with the same interpretation as regression can be seen at table 5.2. which shows the results that transformational leadership styles can explain dynamic abilities by $60 \%$, while transformational leadership styles and dynamic capabilities can explain NGO performance by $73 \%$.

The table 3 will show the results of the hypothesis test. 
Table 3. Hypothesis test

Mean, STDEV, T-Values, P-Values

\begin{tabular}{|l|c|c|c|c|c|}
\hline & $\begin{array}{c}\text { Original } \\
\text { Sample } \\
(\mathrm{O})\end{array}$ & $\begin{array}{c}\text { Sample } \\
\text { Mean (M) }\end{array}$ & $\begin{array}{c}\text { Standard } \\
\text { Deviation } \\
\text { (STDEV) }\end{array}$ & $\begin{array}{c}\text { T Statistics } \\
\text { (|O/STDEV|) }\end{array}$ & P Values \\
\hline $\begin{array}{l}\text { Competitive Intensity (X4) -> NGOs } \\
\text { Performance (X5) }\end{array}$ & 0,041 & 0,132 & 0,186 & 0,218 & 0,827 \\
\hline $\begin{array}{l}\text { Dynamic Capabilities (X2) -> NGOs } \\
\text { Performance (X5) }\end{array}$ & 0,137 & 0,114 & 0,252 & 0,544 & 0,587 \\
\hline $\begin{array}{l}\text { Transformational Leadership (X1) -> } \\
\text { Dynamic Capabilities (X2) }\end{array}$ & 0,785 & 0,800 & 0,055 & 14,250 & 0,000 \\
\hline $\begin{array}{l}\text { Transformational Leadership (X1) -> NGOs } \\
\text { Performance (X5) }\end{array}$ & 0,367 & 0,358 & 0,189 & 1,945 & 0,052 \\
\hline $\begin{array}{l}\text { Moderating Effect X3X2 -> NGOs } \\
\text { Performance (X5) }\end{array}$ & $-0,177$ & $-0,065$ & 0,208 & 0,848 & 0,397 \\
\hline $\begin{array}{l}\text { Moderating Effect X4X2 -> NGOs } \\
\text { Performance (X5) }\end{array}$ & $-0,093$ & $-0,056$ & 0,215 & 0,433 & 0,665 \\
\hline $\begin{array}{l}\text { Organization Structure (X3) -> NGOs } \\
\text { Performance (X5) }\end{array}$ & 0,210 & 0,254 & 0,212 & 0,992 & 0,322 \\
\hline
\end{tabular}

1. H1: Transformational leadership style has a positive effect on the performance of NGO organizations

H1 not accepted as the $\mathrm{t}$ statistic value 1,945 $\leq 1,96$ which states the relation between transformational leadership and NGO performance is not significant though the original sample value 0,367 shows that the direction of the relationship between the two variables is positive;

2. H2:Transformational leadership style have a significant influence on the organizations dynamic capabilities

H2 accepted as the $\mathrm{t}$ statistic value 14,250>1,96 shows that the relationship between trasformational leadership and dynamic capabilities is significantand the original sample value 0,785 shows positive direct relationship between the two variables

3. H3:Effect of dynamic capabilities on organizational performance increases with a more organic organizational structure.

$\mathrm{H} 3$ not accepted as the $\mathrm{t}$ value $0,848 \leq 1,96$ and original sample value $-0,177$ shows negative direct relationship between two variables

4. H4: Effect of dynamic capabilities on organizational performance increases with higher intensity of competition

$\mathrm{H} 4$ not accepted as the $\mathrm{t}$ value $0,433 \leq 1,96$ and original sample value $-0,093$ shows negative direct relationship between two variables

\section{Conclusion}

In the context of NGOs, transformational leadership style does not have a significant effect on NGO performance even though there is a positive relationship between transformational leadership and NGO performance perhaps due to the fact that NGO leadership is now increasingly being applied by broad stakeholder bodies through a series of routine practices supported by 
shared commitment to learn, transform and provide sustainable value to customers Chew and Dovey [42] Whereas in the context of NGOs it turns out that dynamic capabilities can be supported by transformational leadership which reinforces the argument of Cabrales, et al. [37] that only transformational leaders can directly influence dynamic capabilities. This is because transformational leaders are able to promote various sensing, grabbing, and reconfiguration capabilities. In contrast to the findings of this study shows that in the NGO context the organizational structure and intensity of competition have no impact on the performance of the institution.

\section{References}

[1] S. Besrel and H. Sezerel, "Core Competences in Non-Governmental Organizations: A Case Study, Procedia Social and," Behavioral Sciences, vol. 24, pp. 2011-1257.

[2] H. A. Garjar and Randi, Peran Organisasi Masyarakat (Ormas) dan Lembaga Swadaya Masyarakat (LSM) Dalam Menopang Pembangunan di Indonesia. Jurnal Socioglobal.

[3] J. Nelson, The Operation of Non-Govermental Orfganizations in A World of Corporate and Other Code of Conduct, Corporate Social Responsibilities Initiatives, Working. 2007.

[4] A. Ebrahim, "Accountability In Practice: Mechanisms for NGOs," World Development, vol. 31, no. 5, pp. 813-829, 2003.

[5] M. Edwards and D. Hulme, "Too Close For Comfort? The Impact of Official Aid on Nongovernmental Organizations," World Development, Volume, vol. 24, pp. 961-973, Nov. 1998.

[6] D. Lewis, The Management of Non-Governmental Development Organizations An Introduction. London: Routledge, 2001.

[7] M. A. Ramadan and E. Borgonovi, "Performance Measurement and Management in NonGovernmental Organizations, Journal of Business and," in Management (IOSR-JBM), Volume 17, Issue 2.Ver. III, 2015, pp. 70-76.

[8] A. Fowler, "Assessing NGO Performance: Difficulties, Dilemmas and a Way Ahead, in," in Beyond the Magic Bullet: NGO Performance and Accountability in the Post-Cold, E. and Hulme, Ed. Boulder: War World, 1995, pp. 169-186.

[9] D. Lewis, "Theorizing the Organization and Management of Non-Governmental Development Organizations Towards a Composite Approach," Public Management Review, vol. 5, no. 3 2003, pp. 325-344.

[10] D. J. Teece and G. Pisano, "The Dynamic Capabilities of Firms: An Introduction, Industrial and Corporate Change," Volume, vol. 3, 1994.

[11] V. Ambrosini, C. Bowman, and N. Collier, "Dynamic capabilities: An Exploration of How Firms Renew Their Resource Base," British Journal of Management, vol. 20, no. 1, pp. 924, 2009.

[12] K. M. Eisenhardt and J. a Martin, "Dynamic Capabilities: What Are They?, Strategic," Management Journal, Strat. Mgmt. J, vol. 21, pp. 1105-1121, 2000.

[13] D. C. Korten, "Community Organization and Rural Development: A Learning Process Approach,” Public Administration Review, vol. 40, no. 5, p. , Sep. 1980.

[14] M. J. Maloni and M. E. Brown, "Corporate social responsibility in the supply chain: An application in the food industry," Journal of Business Ethics, vol. 68, no. 1, pp. 35-52, 2006.

[15] M. Zollo and S. G. Winter, "Deliberate Learning and the Evolution of Dynamic Capabilities," Organization Science, vol. 13, no. 3, pp. 339-351, May 2002. 
[16] Z. Christoph, Dynamic Capabilities and The Emergence of Intra-Industry Differential Firm Performance: Insight From a Simulation Study, Department of Entrepreneurship INSEAD Boulevard de Constance 77305. Fontainebleau, France, 2000.

[17] M. Glisby and N. Holden, "Applying knowledge management concepts to the supply chain: How Danish firm achieved a remarkable break-through in Japan," Academy of Management Executive, vol. 19, no. 2, pp. 85-89, 2005.

[18] C. E. Helfat and M. A. Peteraf, "The dynamic resource-based view: Capability Lifecycles," Strategic Management Journal Strat. Mgtnt, vol. 24, pp. 991-0, 2003.

[19] Y. Ling, Z. Simsek, M. H. Lubatkin, and J. F. Veiga, "Transformational Leadership's Role in Promoting Corporate Entrepreneurship: Examining the CEO-TMT Interface," The Academy of Management Journal, vol. 51, no. 3, pp. 557-576, Jun. 2008.

[20] M. E. Smith, M. A. Lyles, and M. A. Peteraf, "Dynamic Capabilities: Current Debates and Future Directions," British Journal of Management, vol. 20, no. 1, 2009.

[21] V. J. G. Morales, F. J. L. Montes, Verdu, and A. J. Jover, "The Eff ects of Transformational Leadership on Organizational Performance Through Knowledge and Innovation," British Journal of Management, vol. 19, pp. 299-319, 2008.

[22] M. S. A. M. Shiva and D. Suar, "Transformational Leadership, Organizational Culture, Organizational Effectiveness, and Programme Outcomes in Non-Governmental Organizations, Voluntas," International Journal of Voluntary and Nonprofit Organizations, vol. 23, no. 3, pp. 684-710, Sep. 2012.

[23] Y. Chauhan and S. Kumar, Does founder ownership affect foreign investments? 2017.

[24] R. D. Wilson and J. W. Creswell, "Research Design: Qualitative and Quantitative," 1996.

[25] B. M. Bass and B. J. Avolio, Improving Organizational Effectiveness Through Transformational Leadership. SAGE Publication Inc., USA, 1994.

[26] D. J. Teece, "Explicating Dynamic Capabilities: The Nature And Microfoundations of (Sustainable) Enterprise Performance," Strategic Management Journal, Strat. Mgmt. J, vol. 28, pp. 1319-1350, 2007.

[27] L. Breznik and M. Lahovnik, "Dynamic capabilities and competitive advantage: Finding from Case Study,” Management, vol. 21, pp. 167-185, 2016.

[28] T. O. Nyacanchu, C. Joel, and R. Bonuke, "Moderating Role of Transformational Leadership Behaviour on The Relationship Between Dynamic Capabilities and Performance of Manufacturing Firms in Nairobi County Kenya," International Journal of Economics, Commerce and Management United Kingdom, Vol. V, Issue, vol. 11, Nov. 2017.

[29] D. J. Teece, G. Pisano, and A. Shuen, "Dynamic Capabilities and Strategic Management," Strategic Management Journal, vol. 18, no. 7, pp. 509-533, Aug. 1997.

[30] T. Postmes, M. Tanis, and Bd. Wit, Eds., "Communication and Commitment in Organization: A Social Identity Approach. Group processes and Intergroup," Relations, vol. 4, no. 3, pp. 227-246, 2001.

[31] M. A. Hitt and B. B. Tyler, "Strategic decision models: Integrating different perspectives," Strategic Management Journal, vol. 12, no. 5, pp. 327-351, 1991.

[32] O. Michelsen, T. E. Fet, and A. Dahlsrud, "Eco-friendly extended supply chains: A case study of furniture production," Journal of Environmental Management, vol. 79, no. 3, pp. 290-297, 2006.

[33] M. E. Porter, Competitive Strategy Techniques for Analyzing Industries and Competitors. New York: Free Press, 1980.

[34] H. S. Jenatabadi, "An Overview of Organizational Performance Index: Definitions and Measurements," Department of Science and Technology Studies University of Malaya, Kuala Lumpur, Malaysia. 
[35] A. Ghezzi and A. Cavallo, “Agile Business Model Innovation in Digital Entrepreneurship: Lean Startup Approaches, Journal of Business Research. Elsevier, (June), pp. 0-1. doi: 10.1016/j.jbusres.2018.06.013.," 2018.

[36] Dragoș, "Cătălin Apostu, Non-Governmental Organization Leadership And Development: A Review of The Literature, Change and," Leadership, vol. 7, 2013.

[37] C. A. Lopez., M. B. Barrachina, and F. M. Diaz, "Leadership and Dynamic Capabilities: The Role of HR systems,” Personnel Review, vol. 46, no. 2, pp. 255-276, 2017.

[38] D. Schwenger, T. Straub, and B. Stefano, "Non-Governmental Organizations: Strategic Management for A Competitive World," Journal of Business Strategy, vol. 35, no. 4, pp. $11-19$.

[39] S. Mathos and J. Hall, "Integrating sustainable development in the supply chain: The case of life cysle assessment in oil and gas and agricultural biotechnology," Journal of Operations Managment, vol. 25, no. 6, pp. 1083-1102, 2007.

[40] FME, "SwotAnalysis: Strategy Skills, Free-Managment-Ebooks. doi: http://www.freemanagement-ebooks.com/dldebk-pdf/fme-pestle-analysis.pdf.," 2013.

[41] H. K. Anhaier, Non Profit Organization, Theory, Management. New York: Policy, Routledge, 2005.

[42] E. Chew and K. A. Dovey, Learning to Create Sustainable Value in Turbulent Operational Contexts: The Role of Leadership in Practices, The Learning Organization, vol. 21. . 